\title{
Comparative Analyses of Hairless-Leaf and Hairy-Leaf Type Individuals in Aster hispidus var. insularis (Asteraceae)
}

\author{
Teruomi Sunami ${ }^{1}$, Kyohei Ohga ${ }^{2}$, Miwako Muroi ${ }^{2}$, Hiroshi Hayakawa ${ }^{1}$, Jun Yokoyama ${ }^{3}$, Katsura Ito ${ }^{1}$, Shin-ichi \\ Tebayashi $^{1}$, Ryo Arakawa ${ }^{1} \&$ Tatsuya Fukuda ${ }^{1}$ \\ ${ }^{1}$ Faculty of Agriculture, Kochi University, Japan \\ ${ }^{2}$ Graduate School of Integrated Arts and Sciences, Kochi University, Japan \\ ${ }^{3}$ Faculty of Science, Yamagata University, Japan \\ Correspondence: Tatsuya Fukuda, Faculty of Agriculture, Kochi University, Japan. Tel: 81-888-645-140. E-mail: \\ tfukuda@kochi-u.ac.jp
}

Received: August 2, 2012 Accepted: September 5, 2012 Online Published: September 15, 2012

doi:10.5539/jps.v2n1p1 URL: http://dx.doi.org/10.5539/jps.v2n1p1

\begin{abstract}
The distribution of Aster hispidus Thunb. var. insularis (Makino) Okuyama is limited to the coastal areas of southwestern Shikoku. This species has been described as having fatter stems, thicker leaves, and glabrous stems and leaves ciliate on margin. We have found many individuals that ranged from having no hair to many hairs on the abaxial side of the leaves in this variety. We measured the number of leaf hairs, degree of herbivory, and stomatal density of leaves of $A$. hispidus var. insularis. Two types of $A$. hispidus var. insularis for the presence or absence of leaf hairs were obsereved. The degree of herbivory did not differ significantly between these two types, however, the stomatal density was lower in the hairy-leaf-type individuals than in the hairless-leaf-type individuals.
\end{abstract}

Keywords: Aster hispidus var. insularis, leaf, hair, stomata

\section{Introduction}

Aster hispidus Thunb. (Asteraceae) is distributed from China, Korea, and Japan, inhabits open fields and grasslands in lowland areas, and comprises five infraspecific taxa; A. hispidus var. hispidus, A. hispidus var. insularis (Makino) Okuyama, A. hispidus var. tubulosus K. Asano, A. hispidus var. leptocladus (Makino) Okuyama, and A. hispidus var. koidzumianus (Kitam.) Okuyama (Yonekura \& Kajita, 2003; Igari, 2007). Among them, A. hispidus var. insularis is limited to along the seashore of southwestern Shikoku with fatter stems and thicker leaves (Kitamura, 1981, as Heteropappus hispidus (Thunb.) Less. subsp. insularis (Makino) Kitam.). Tunala et al. (2012) conducted a morphological and anatomical analyses and reported that $A$. hispidus var. insularis had larger and thicker stem leaves than that of $A$. hispidus var. hispidus, and it was caused by increasing cell size of stem leaves. In addition to these traits, $A$. hisipidus var. insularis is distinguished from $A$. hispidus var. hispidus in having glabrous stems and leaves ciliate on the margin (Kitamura, 1981; Ito \& Soejima, 1995). Many studies recognized that $A$. hispidus var. insularis had no hair excluding leaves ciliate on the margin (Makino, 1898; Kitamura, 1981; Ito \& Soejima, 1995; Igari, 2007). However, we found many different individuals of $A$. hispidus var. hispidus ranging from no hair to many hairs on the stems and on the abaxial side of leaves, although it had fatter stems and thicker leaves, which were characteristics to A. hispidus var. hispidus. These individuals show sympatry in various areas of the seashore of southwestern Shikoku. However, the roles of the leaf-hair variation among the individuals of $A$. hispidus var. insularis is not known.

In general, leaf hairs were widespread in all angiosperms, occurring on the aerial surfaces of most species (Johnson, 1975). In many studies, the leaf hairs in many species were thought to serve as a mechanical defense against attack by herbivores (Hoffman \& McEvoy, 1985; Gross \& Price, 1988; Tuberville et al., 1996; Mauricio \& Rausher, 1997; Elle et al., 1999; Hare \& Elle, 2002; Agrawal, 2004; Handley et al., 2005; Valkama et al., 2005). Leaf hairs may also function to protect plants from abiotic stressors such as drought (Ehleringer, 1982; Grammatikopoulos \& Manetas, 1994; Espigares \& Peco, 1995; Perez-Estrada et al., 2000), temperature (Ehleringer, 1982; Perez-Estrada et al., 2000), and heavy metal toxins (Salt et al., 1995; Gutierrez-Alcala et al., 2000). The accumulation of salts owing to drought in the soil in coastal areas, where A. hispidus var. insularis is 
distributed, decreases the soil's osmotic potential and plants suffer from dehydration; therefore, the leaf hairs of A. hispidus var. insularis could have a function against drought. In addition, the stomatal density was correlated to the transpiration rate (Ouedraogo \& Hubac 1982), suggesting that it would be interesting to measure the stomatal density of the hairless- and hairy-leaf types of A. hispidus var. insularis, because it might reveal a part in determining susceptibility to drought. By studying the functions of the leaf hairs, one can examine the interacting abiotic and biotic factors in A. hispidus var. insularis. Therefore, we measured morphologies and functions of the hairs on the stem leaves and the stomatal density in A. hispidus var. insularis individuals with and without leaf hairs.

\section{Materials and Methods}

The samples of $A$. hispidus var. insularis collected in this study were used from the seashore field in 2011. All samples had typical morphologies of $A$. hispidus var. insularis in the characters of the fatter stems and thicker leaves. The leaf hairs were counted for all samples of $A$. hispidus var. insularis. Then, A. hispidus var. insularis was categorized into two types, hairless and hair types, by puberulous or glabrous leaves. For the degree of herbivory, we analyzed 30 individuals (Kashiwajima) and 32 individuals (Komomisaki) of hairless type and 30 individuals (Kashiwajima) and 31 individuals (Komomisaki) of hair type of $A$. hispidus var. insularis (Figure 1, Table 1). To calculate the degree of herbivory, we observed the percentage of herbivore damage and calculated the size of all the stem leaves (summarized leaf length $\mathrm{x}$ leaf width) on each individual. With these measurements, we calculated the percentage values of the degree of herbivory on all individuals (herbivore-damaged size divided by entire leaf size).

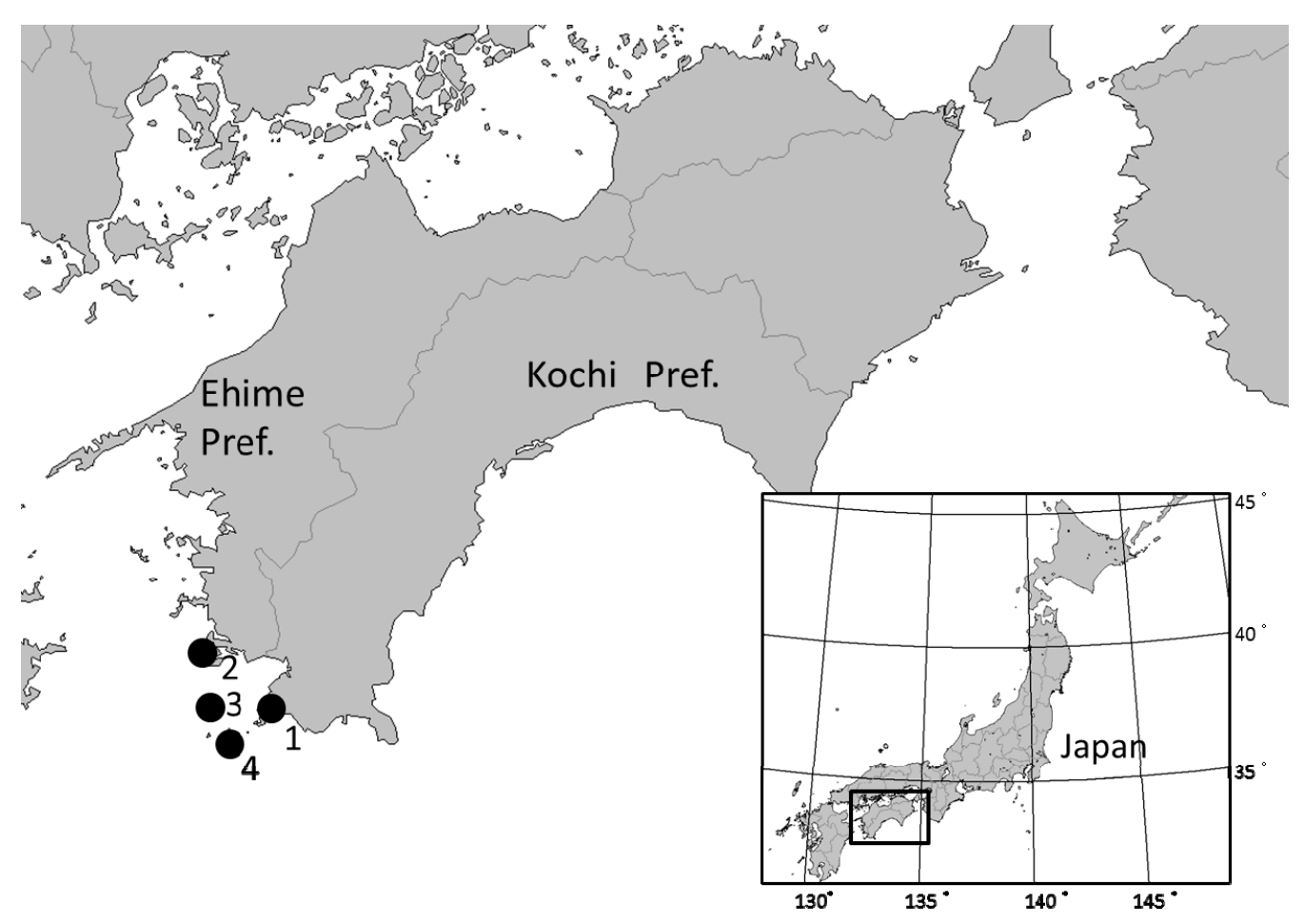

Figure 1. Sampling localities (No. 1-4) observed in this study

Locality names of No. 1 to 4 are Kashiwajima, Komomisaki, Ugurujima, and Okinoshima, respectively. See Table 1 for additional information. 
Table 1. Sampling localities used in this study

\begin{tabular}{|c|c|c|c|c|c|}
\hline \multirow{2}{*}{$\begin{array}{l}\text { Locality } \\
\text { Name }\end{array}$} & \multirow{2}{*}{$\begin{array}{l}\text { Locality } \\
\text { No. }\end{array}$} & \multirow{2}{*}{ Locality } & \multicolumn{2}{|c|}{ Number of individuals } & \multirow{2}{*}{$\begin{array}{l}\text { Latitude and } \\
\text { longitude }\end{array}$} \\
\hline & & & hairless-leaf & hairy-leaf & \\
\hline \multirow{2}{*}{ Kashiwajima } & \multirow{2}{*}{1} & \multirow{2}{*}{$\begin{array}{l}\text { Kochi Prefecture, Hata-Gun, } \\
\text { Otsuki-Cho, Kashiwajima }\end{array}$} & \multirow{2}{*}{65} & \multirow{2}{*}{58} & N $32^{\circ} 78^{\prime}$ \\
\hline & & & & & E $132^{\circ} 64^{\prime}$ \\
\hline \multirow{2}{*}{ Komomisaki } & \multirow{2}{*}{2} & \multirow{2}{*}{$\begin{array}{c}\text { Ehime Prefecture, Minamiuwa-Gun, } \\
\text { Ainan-Cho, Komomisaki }\end{array}$} & \multirow{2}{*}{32} & \multirow{2}{*}{31} & N $32^{\circ} 91^{\prime}$ \\
\hline & & & & & E $132^{\circ} 48^{\prime}$ \\
\hline \multirow{2}{*}{ Ugurujima } & \multirow{2}{*}{3} & \multirow{2}{*}{$\begin{array}{l}\text { Kochi Prefecture, Sukumo City, } \\
\text { Okinoshima-Cho, Ugurujima }\end{array}$} & \multirow{2}{*}{6} & \multirow{2}{*}{0} & N $32^{\circ} 80^{\prime}$ \\
\hline & & & & & E $132^{\circ} 49^{\prime}$ \\
\hline \multirow{2}{*}{ Okinoshima } & \multirow{2}{*}{4} & \multirow{2}{*}{$\begin{array}{l}\text { Kochi Prefecture, Sukumo City, } \\
\text { Okinoshima-Cho, Okinoshima }\end{array}$} & \multirow{2}{*}{17} & \multirow{2}{*}{7} & N $32^{\circ} 72^{\prime}$ \\
\hline & & & & & E $132^{\circ} 55^{\prime}$ \\
\hline
\end{tabular}

Locality No. Corresponds to that given in Figure 1.

To measure stomatal density, we collected 58 and 35 samples of $A$. hispidus var. insularis with and without hairs, respectively, from Kashiwajima, Okinoshima, and Ugurujima in southwestern Shikoku (Figure 1, Table 1). Five fully-expanded stem leaves at the middle part of plant height were analyzed from each individual. We used the average value of five leaves for each individual. We measured the leaf size and counted the leaf hairs on the abaxial side of stem leaves. To measure the stomatal density of a leaf, the leaf surface was replicated using Suzuki's Universal Micro-Printing (SUMP) method. The middle part of the blade along the midrib was analyzed to determine the stomatal density. Replicas of each leaf $\left(1 \mathrm{~cm}^{2}\right)$ were prepared in order to count the stomatal density. The SUMP images were examined twice for each leaf using a light microscope. The collected data were analyzed using $t$-test and $U$-test to compare the characteristics.

\section{Results and Discussion}

The number of leaf hairs varied from zero to over 300 (Figure 2), suggesting that $A$. hispidus var. insularis has not only hairless-leaf type, but also hairy-leaf type. From this result, we divided $A$. hispidus var. insularis into two types by of presence or absence of leaf hairs. The leaf size values of hairless-leaf type and hairy-leaf type individuals were $222.0 \pm 158.0 \mathrm{~mm}^{2}$ and $219.2 \pm 149.9 \mathrm{~mm}^{2}$, respectively with no significant difference between them (Table 2). The relationship between the leaf size and leaf hair number was not significantly correlated in each leaf $\left(r^{2}=0.1387\right)$, suggesting that the number of leaf hairs was not determined allometrically. The degree of herbivory of hairless-leaf type and hairy-leaf type individuals were $4.6 \pm 6.8 \%$ and $8.0 \pm 9.3 \%$, respectively, in the Kashiwajima population and $3.9 \% \pm 7.2 \%$ and $3.6 \% \pm 8.5 \%$, respectively, in the Komomisaki population (Figure 3). There was no significant difference between these traits, suggesting that the leaf hairs play a minor role in mechanical defense against herbivore attack. On the contrary, the stomatal density of hairless-leaf type and hairy-leaf type individuals of $A$. hispidus var. insularis were $108.2 \pm 17.7$ and $96.0 \pm 13.0$, respectively, with a significant difference between the values (Table 2). Thus, there were fewer stomata in hairy-leaf-type individuals than in the hairless-leaf-type individuals.

Table 2. Morphological and anatomical measurements (average \pm standard deviation) of Aster hispidus var. insularis

\begin{tabular}{lllc}
\hline Trait & hairless-leaf $(\mathrm{n}=58)$ & hairy-leaf $(\mathrm{n}=35)$ & Significance \\
\hline Morphological measurements & & & \\
Leaf length $(\mathrm{mm})$ & $30.3 \pm 9.7$ & $30.2 \pm 9.5$ & $\mathrm{n} . \mathrm{s}$ \\
Leaf width $(\mathrm{mm})$ & $6.5 \pm 2.2$ & $6.4 \pm 2.2$ & $\mathrm{n} . \mathrm{s}$ \\
Leaf size $\left(\mathrm{mm}^{2}\right)$ & $222.0 \pm 158.0$ & $219.2 \pm 149.9$ & n.s \\
Number of leaf hair $(\mathrm{N})$ & -------- & $153.4 \pm 97.3$ & --- \\
Anatomical measurements & & & \\
Stomatal density $\left(\mathrm{N} / \mathrm{mm}^{2}\right)$ & $108.2 \pm 17.7$ & $96.0 \pm 13.0$ & $*$ \\
\hline $\mathrm{P}<0.05$. n.s. $: \mathrm{P}>0.05$ & & &
\end{tabular}




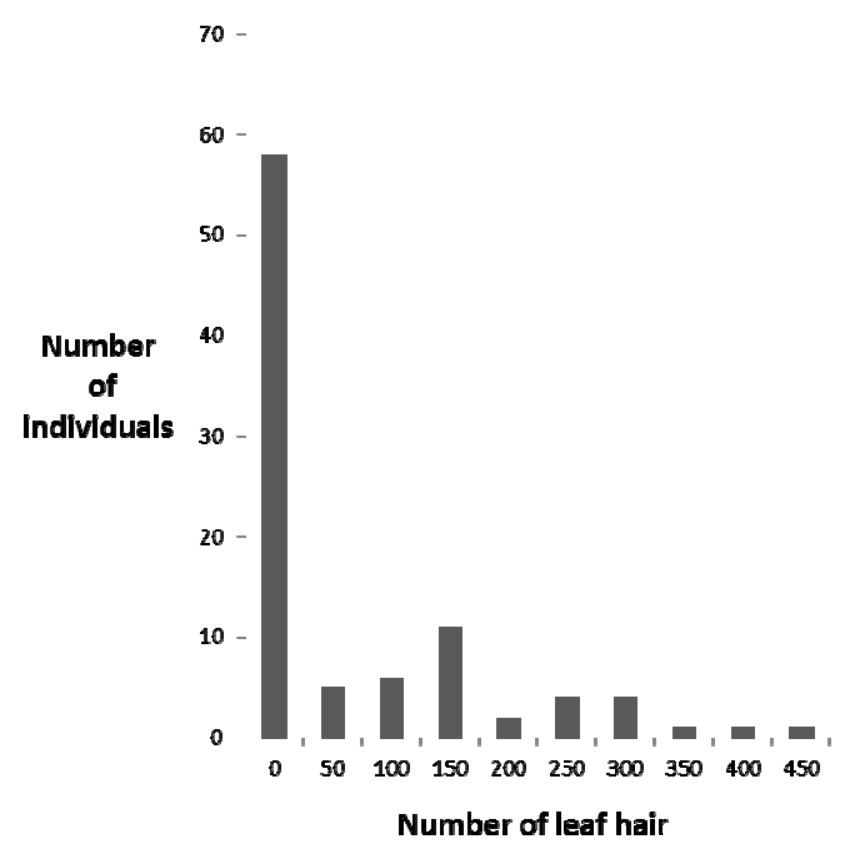

Figure 2. Histogram of hair number on the abaxial side of leaf
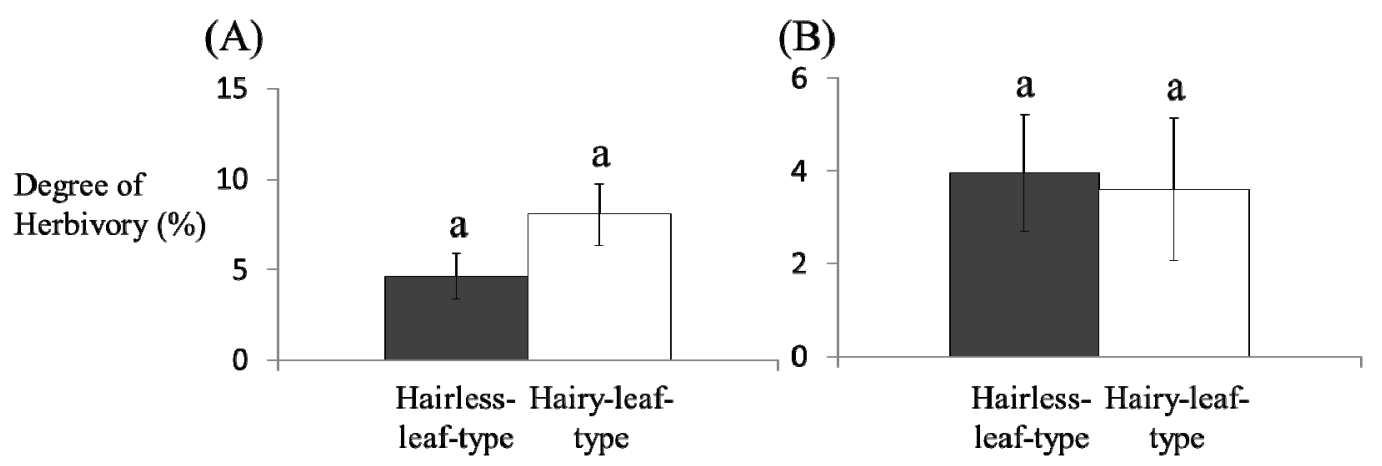

Figure 3. Comparison of the degree of herbivory between the hairless-leaf- and hairy-leaf-type individuals in Aster hispidus var. insularis

White boxes indicate hairless-leaf-type and black boxes indicate hairy-leaf-type A. hispidus var. insularis individuals. (A) Kashiwajima; (B) Komomisaki. Same alphabetica (a) indicates no significant difference on $U$-test $(p<0.05)$.

It was unclear whether reduction in the stomatal density of $A$. hispidus var. insularis had any adaptive significance. In general, the leaves of the coastal plants were more succulent than those of the inland plants because they can store water and were associated with environments subjected to conditions of drought (Uno et al. 2001). In fact, we found various coastal plants with succulent leaves such as Cirsium maritimum Makino (Asteraceae), Dianthus japonicus Thunb. (Caryophyllaceae), and Canavalia lineata (Thunb.) DC. (Fabaceae) in our study areas. Considering the drought conditions of coastal areas, a decrease in the stomatal density of a leaf was another adaptation that helped prevent excess water loss, because the fewer the stomata, the lesser transpirational water loss (Campbell et al., 1999). Our results indicated that the stomatal density was significantly less in the hairy-leaf-type individuals than in the hairless-leaf-type individuals in A. hispidus var. insularis.

Additionally, it is very interesting to note that the population of hairy-leaf type individuals of $A$. hispidus var. insularis was sympatric to that of hairless-leaf type individuals growing in various areas (Table 1). Kitamura (1981) and Igari (2007) recognized A. hispidus var. insularis had no hairs on leaves and stems in their reports. 
Thus, we considered that the effects from A. hispidus var. hispidus through hybridization between them would be small for the variation of leaf hairs. Fujikawa et al. (2009) reported the presence of hairy-leaf type individuals using voucher specimens at the MBK herbarium. Because A. hispidus var. insularis and A. hispidus var. hispidus cannot be distinguished on the basis of puberulous and glabrous stem leaves, further studies are necessary to investigate more detailed morphological analysis for the two varieties, including the characters of leaf hair and stomatal density. From these results, we propose the following four hypotheses for the leaf hair variation in $A$. hispidus var. insularis individuals: (1) the individuals have gained the divergence of leaf hair variation, after speciation of A. hispidus var. insularis and A. hispidus var. hispidus, (2) A. hispidus var. insularis contained the plesiomorphous polymorphic characters for leaf hair variation at speciation from A. hispidus var. hispidus, (3) A. hispidus var. insularis have gained the divergence of leaf hair variation through hybridization between glabrous A. hispidus var. insularis and puberulous A. hispidus var. hispidus, and (4) A. hispidus var. insularis evolved fewer times with or without leaf hair variations from A. hispidus var. hispidus. Yokoo et al. (2009) revealed the phylogenetic relationships among $A$. hispidus varieties that the edaphic varieties, $A$. hispidus var. insularis, may have derived allopatrically. Thus, among our hypotheses, hypothesis four could be the most candidate hypothesis. Interestingly, Chrysanthemum japonense (Makino) Nakai var. ashizuriense Kitam is limited to the distribution of this area (Fujikawa et al., 2009), which species has more hairs on abaxial side of the leaves than those of closely related taxa, C. japonense var. japonense (Kitamura, 1981). These results imply that it is likely to select the hairly-leaf type individuals of $A$. hispidus var. insularis and $C$. japonense in this area. Our results of the presence of individuals with leaf hair and reduction of stomatal density might be one of effective adaptation mechanisms and increasing divergence for coastal areas. Therefore, ecological investigations of the leaf-hair type of $A$. hispidus var. insularis individuals will be necessary in the future.

\section{Acknowledgements}

We wish to thank Tsuchiya Y., Yoshimi Y., Isomoto S., Matsuyama K., Yokoyama N., Kumekawa Y., Kakimoto N., and Takei S. for providing us with much-needed assistance. This study was partly supported by Grant-in-Aid for Scientific Research from the Ministry of Education, Science and Culture of Japan (to TF).

\section{References}

Agrawal, A. A. (2004). Resistance and susceptibility of milkweed: competition, root herbivory, and plant genetic variation. Ecology, 85(8), 2118-2133. http://dx.doi.org/10.1890/03-4084

Campbell, N. A., Reece, J. B., \& Mitchell, L. G. (1999). Biology fifth edition. Wesley Longman, New York.

Ehleringer, J. R. (1982). The influence of water stress and temperature on leaf pubescence development in Encelia farinosa. American Journal of Botany, 69(5), 670-675. http://dx.doi.org/10.2307/2442956

Elle, E., van Dam, N. M., \& Hare, J. D. (1999). Cost of glandular trichomes, a "resistance" character in Datura wrightii Regel (Solanaceae). Evolution, 53(1), 22-35. http://dx.doi.org/10.2307/2640917

Espigares, T., \& Peco, B. (1995). Mediterranean annual pasture dynamics: impact of autumn drought. Journal of Ecology, 83(1), 135-142. http://dx.doi.org/10.2307/2261157

Fujikawa, K., Horiuchi, K., Ogawa, M., Kadota, Y., \& Maeda, A. (2009). Asteraceae (Compositae). In: Kochi Prefecture \& Makino Memorial Foundation of Kochi Prefecture (eds.). Flora of Kochi. (pp. 465-515). Kochi Prefecture \& Makino Memorial Foundation of Kochi Prefecture, Kochi. (in Japanese).

Grammatikopoulos, G., \& Manetas, Y. (1994). Direct absorption of water by hairy leaves of Phlomis fruticosa and its contribution to drought avoidance. Canadian Journal of Botany, 72(12), 1805-1811. http://dx.doi.org/10.1139/b94-222

Gross, P., \& Price, P. W. (1988). Plant influences on parasitism of two leafminers: a test of enemy-free space. Ecology, 69(5), 1506-1516. http://dx.doi.org/10.2307/1941648

Gutierrez-Alcala, G., Gotor, C., Meyer, A. J., Fricker, M., Vega, J. M., \& Romero, L. C. (2000). Glutathione biosynthesis in Arabidopsis trichome cells. Proceedings of the National Academy of Sciences, USA, 97(20), 11108-11113. http://dx.doi.org/10.1073/pnas.190334497

Handley, R., Ekbom, B., \& Ågren, J. (2005). Variation in trichome density and resistance against a specialist insect herbivore in natural populations of Arabidopsis thaliana. Ecological Entomology, 30(3), 284-292. http://dx.doi.org/10.1111/j.0307-6946.2005.00699.x

Hare, J. D., \& Elle, E. (2002). Variable impact of diverse insect herbivores on dimorphic Datura wrightii. Ecology, 83, 2711-2720. http://dx.doi.org/10.1890/0012-9658(2002)083[2711:VIODIH]2.0.CO;2 
Hoffman, G. D., \& McEvoy, P. B. (1985). Mechanical limitations on feeding by meadow spittlebugs Philaenus spumarius (Homoptera: Cercopidae) on wild and cultivated host plants. Ecol. Entomol, 10(4), 415-426. http://dx.doi.org/10.1111/j.1365-2311.1985.tb00739.x

Igari, M. (2007). Wild Asteraceae in Japan. (pp. 196-203). Yama-kei publisher, Tokyo (in Japanese).

Ito, M., \& Soejima, A. (1995). Aster. In; Iwatsuki K. Yamasaki K. Boufford D.E. and Ohba H. (eds.), Flora of Japan (Vol. IIIb, Angiospermae, Dicotyledoneae, Sympetalae (b)). (pp. 59-73). Kodansha, Tokyo.

Johnson, H. B. (1975). Plant pubescence: an ecological perspective. Botanical Review, 41(3), 233-253. http://dx.doi.org/10.1007/BF02860838

Kitamura, S. (1981). Compositae (Asteraceae). In Y. Satake, J. Ohwi, S. Kitamura, S. Watari, \& T. Tominari (Eds.), Wild Flowers of Japan Herbaceous Plants Vol. III. (pp. 156-235). Tokyo: Heibonsha Ltd. (in Japanese).

Makino, T. (1898). Planta Japonenses nova vel minus cognita. Botanical Magazine of Tokyo, 12, 67-74.

Mauricio, R., \& Rausher, M. D. (1997). Experimental manipulation of putative selective agents provides evidence for the role of natural enemies in the evolution of plant defense. Evolution, 51(5), 1435-1444. http://dx.doi.org/10.2307/2411196

Ouedraogo, M., \& Hubac, C. (1982). Effect of far red light on drought resistance of cotton. Plant Cell Physiol, 23(7), 1297-1303.

Perez-Estrada, L. B., Cano-Santana, Z., \& Oyama, K. (2000). Variation in leaf trichomes of Wigandia urens: environmental factors and physiological consequences. Tree Physiology, 20(9), 629-632. http://dx.doi.org/10.1093/treephys/20.9.629

Salt, D. E., Prince, R. C., Pickering, I. J., \& Raskin, I. (1995). Mechanisms of cadmium mobility and accumulation in Indian Mustard. Plant Physiology, 109(4), 1427-1433.

Tuberville, T. D., Dudley, P. G., \& Pollard, A. J. (1996). Responses of invertebrate herbivores to stinging trichomes of Urtica dioica and Laportea canadensis. Oikos, 75(1), 83-88. http://dx.doi.org/10.2307/3546324

Tunala., Hayakawa, H., Minamiya, Y., Gale, S. W., Yokoyama, J., Arakawa, R., \& Fukuda, T. (2012). Foliar adaptations in Aster hispidus var. insularis (Asteraceae). Journal of Plant Studies, 1(2), 19-25. http://dx.doi.org/10.5539/jps.v1n2p19

Uno, G., Storey, R., \& Moore, R. (2001). Leaves and the movement of water. In G. Uno, R. Storey, \& R. Moore (Eds.), Princeples of botany. (pp. 205-230). NY: The McGraw-Hill.

Valkama, E., Koricheva, J., Salminen, J. P., Helander, M., Saloniemi, I., Saikkonen, K., \& Pihlaja, K. (2005). Leaf surface traits: overlooked determinants of birch resistance to herbivores and foliar micro-fungi? Trees Structure and Function, 19(2), 191-197. http://dx.doi.org/10.1007/s00468-004-0380-5

Yokoo, T., Kobayashi, S., Fujikawa, K., Oginuma, K., Mitsui, Y., Ikeda, H., \& Setoguchi, H. (2009). Genetic Structure among and within Populations of Serpentine Endemic Heteropappus hispidus ssp. leptocladus

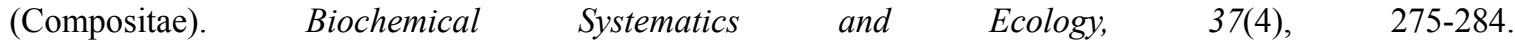
http://dx.doi.org/10.1016/j.bse.2009.04.012

Yonekura, K., \& Kajita, T. (2003). BG Plants Japanese name- Scientific name index (YList). Retrieved July 16, 2012 from http://bean.bio.chiba-u.jp/bgplants/ylist_main.html 